\title{
MOVERS
}

\section{Steven Williams, president, Wildlife Management Institute, Washington DC}

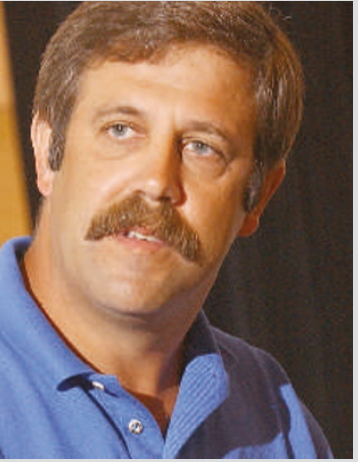

2002-05: Director, US Fish and Wildlife Service 1995-2001: Secretary, Kansas Department of Wildlife and Parks, Topeka 1992-95: Deputy executive director, Pennsylvania Game Commission, Harrisburg 1989-92: Assistant director for wildlife, Massachusetts Division of Fisheries and Wildlife, Westboro

Steven Williams has been a rock-skipping, wildernessrambling, wildlife-ogling guy for as long as he can remember. Not surprisingly, he turned those interests into degrees in biology and resource management. His path, however, has gone from the wilderness to the halls of US national government and back again.

Wanting to focus on applied management following his PhD in Forest Resources at Pennsylvania State University, Williams began working as a wildlife biologist at the Massachusetts Division of Fisheries and Wildlife. $\mathrm{He}$ continued with three different state agencies for the next 17 years, moving his way up management. He got his first taste of the politics of civil service in 1995, when he lost his job as deputy executive director of the Pennsylvania Game Commission for what he describes as political reasons. It was his greatest challenge. "At that time, I was really questioning whether to continue in this profession," he says. Following advice from mentors, he decided to keep going. And he's glad he did. "The experience opened the door to the two best career experiences I've had in my life," he says.

Williams became the secretary of the Kansas Department of Wildlife and Parks. Noticed for his ability to bring different stakeholders together to resolve naturalresource conflicts, he was asked to become director of the US Fish and Wildlife Service. Although he loved the position, in which he spent three years, the red tape in Washington DC often proved a hurdle.

He left the federal post earlier this year to take up the position of president of the Wildlife Management Institute (WMI) based in Washington DC. Being at a non-profit organization dedicated to science-based management allows him to focus more on conservation, he says. At the Fish and Wildlife Service, he was pulled in many directions. But the WMI's mission is more centred on traditional conservation issues such as habitat and population management.

Williams says that the best advice he can give young scientists, other than finding a good spouse, is to "set yourself apart" by combining skill sets in a unique way. In gaining a background in statistics and the then nascent field of geographic information systems, he says, he offered more value to his future employers. In fact, his first employer has since told him that they hired him to see how those skills could help them. He has proved that the chance was worth taking.

Virginia Gewin

\section{MENTORS \& PROTEGES}

\section{Approachable award-winner}

This year, the Graduate Students'

Association at the University of

California, San Francisco, honoured my adviser, stem-cell biologist Renee Reijo

Pera, with its annual Outstanding

Faculty Mentorship Award. I was one of

five current or former students who wrote nomination letters filled with examples of how Renee consistently praises our strengths, shores up our weaknesses, and shows real concern for our career development and personal well-being.

One of Renee's strengths is her approachability. Every student in our lab has a regular weekly meeting with Renee, no matter how full her schedule is. Even when she's out of town, she stays in close e-mail contact. I remember once when Renee was rushing to finish writing a huge grant proposal, she still made time at the last minute to go over slides for a presentation I was giving the next day. Renee's availability and approachability make us feel comfortable in the lab and keep our projects focused and on track.

Renee also prepares us for a career in science by repeatedly encouraging us to present posters, give talks, take relevant classes and write papers. She lets us work independently, but provides help when needed. She also helps us set up collaborations with faculty members from other departments and institutions, so that we can develop our own network of contacts. As we approach graduation, Renee has spent hours talking with us about different career options, what to look for in an employer, and how best to present ourselves.

Renee encourages us to make time for personal or family issues and extracurricular activities, and doesn't concern herself with our 'face time' in the lab. Many of us have been active in student organizations on campus, and she has often volunteered for activities when we needed involvement from faculty members. She understands that students who lead balanced lives come to work ready to tackle experiments with energy and a clear mind.

Simply put, Renee is a good mentor because she cares enough to put the time and effort in to helping us - a trait that is, unfortunately, not common enough.

At the University of California, San Francisco, we are organizing a mentorship course for faculty members and students. We hope that these courses and role models such as Renee will help to improve the training of the next generation of scientists. Joyce Tung is a graduate student at the University of California, San Francisco. succeed no matter what we endeavour

\section{GRADUATE JOURNAL}

\section{Post-holiday revelations}

I have been back in the laboratory for two weeks after a break between finishing my master's and starting my doctorate. Coming back, I realized how much I had missed thinking about scientific problems during my holiday, as well as planning experiments and reading papers. There is no doubt: research now belongs in my life.

The other thing I immediately sensed is how tedious everyday lab life can be. I have to prepare all the materials for my experiments. If a reagent runs out I have to make a note, order and restock. If I don't, the experiment will not happen. Organizational skills are very important. This part of the job may not be the most scientifically interesting, but I see now that there is a benefit. I always wondered why scientists were primary targets for headhunters scouting for major consulting companies. I would never drop out of science to wear a suit and advise business people every day. But I realize how problem analysis, time and resource management skills, and the ability to work independently - so crucial in the lab - are also a fantastic set of qualities for any job type.

But I'm still not tempted to sell my skills to private industry. I have three more years to go before I finish my doctorate. Plenty to learn, plenty to organize. Tobias Langenhan is a graduate student in neuroscience at the University of Oxford, UK. 